\title{
ECONOMIC DIMENSION OF DIGITIZATION IN RURAL AREAS
}

\author{
Iryna Kramar, Nataliia Marynenko, Oksana Mischuk, Viktoria Bukhta, Roman Sherstiuk \\ Ternopil Ivan Puluj National Technical University, Ukraine \\ ira_kramar@yahoo.com,n_marynenko@ukr.net,oksanamishchuk61@gmail.com, \\ v_bukhta@i.ua, romsher85@gmail.com
}

\begin{abstract}
Currently the agrifood sector is recognized to play a crucial role in the sustainable development of the world, as well as to be the main source of income and employment in rural areas. The economic sectors' share in the structure of gross value added and employment level in urban and rural areas in Ukraine are analyzed. Based on this analysis, it is determined that agriculture remains significant for livelihoods and employment in the country. At the same time, as we are living in the Fourth Industrial Revolution, it is pointed out that agriculture itself will not be able to achieve sustainable growth, if not combined with technology. The publication aims to stress on the importance of digital technologies in agriculture to meet the needs of global population and maintain sustainable growth. To define the interrelation between technology and the agrifood sector in Ukraine the publication goes on to explore Ukraine's performance according to the IMD World Digital Competitiveness Ranking and key drivers of Industry 4.0 in the country. The article focuses on such basic areas to identify the state of digital technologies in agriculture as economic, social and cultural, environmental ones. The attention is paid to the specifics of Digital Agriculture and key factors for the transition to digital farming in Ukraine according to the "Digital Agenda 2020". Main benefits and challenges of digitization in rural areas are described. Mechanisms for the effective functioning of digital agriculture are shown.
\end{abstract}

Keywords: digitization, digital agriculture, digital economy, rural areas, urbanization.

\section{Introduction}

Sustainable development of the world is possible to be achieved only with the combination of different tools to be used in all areas of human lives, whilst agriculture and food sector play a crucial role. The United Nations Department of Economic and Social Affairs (UN DESA) projects the global population to grow at $20 \%$ and reach over 9.7 billion in 2050 [1] and 11.2 billion in 2100 [2], which means that there will be a significant increase in food demand.

It was also noticed that people who mostly suffered from food insecurity in 2018 lived in countries with poor economic development or countries facing economic slowdowns or downturns, which in turn, often cause a rise of unemployment and decline in incomes, currency depreciation and high food prices [3]. Moreover, today more than 4 billion people around the world live in urban areas, which is expected to be over 6.4 billion (out of projected 9.7 billion people) by 2050 [4]. This testifies that a huge shift in moving from rural to urban areas together with the overall growth of the world's population will add over 2.5 billion people more to urban areas by 2050. This stresses the importance of rural areas development globally in order to slowdown the urbanization processes and maintain sustainability. As the agricultural sector remains a major source of livelihoods in rural areas and its major part of production is devoted to satisfying food demand [5], it remains critical for solving the above mentioned problems, or at least not allowing them to grow.

Although, the agricultural sector is now facing many challenges, one of which is the technology use in rural areas, more specifically "digitization". Therefore, the goal of the article is to describe different aspects of rural areas digitization, in the agrifood sector in particular, and how this process influences the countries' economic development and global sustainability. To achieve the goal there are defined such objectives of the research paper as: to identify the state of the agrifood sector in the world and its role in achieving global sustainability; to establish relation between digitization in rural and urban areas and level of country's economic development, in particular, employment rate, on the example of Ukrainian economy; to describe key drivers of Ukraine's digital development; to develop mechanisms for digital agriculture effective use and determine their effects on economic, social and cultural areas of life.

\section{Materials and methods}

The research materials were scientific researches of national and foreign scientists in the field of digitization in rural areas from the economic viewpoint. The methodological basis of the research was an interdisciplinary approach, including scientific discourse on digitization and economics. Reports on 
different aspects of digital economy, rural development and digitization in agricultural sector, as well as statistical data and official ranking analysis were used. To conduct the research analytical, logical, scientific deduction and induction, comparison and qualitative analyses were used.

\section{Results and discussion}

The UN Sustainable Development Goal (SDG) Target 2 "Zero Hunger" points out the importance of food security problem which is currently taking place in the world. There are two indicators to monitor SDG Target 2: the prevalence of undernourishment and prevalence of moderate or severe food insecurity based on the Food Insecurity Experience Scale (FIES) [3]. According to the Food and Agriculture Organization of the United Nations (FAO), today more than 820 million people suffer from hunger, which corresponds to about one in every nine people in the world [5]. Also 9.2 percent of the world population (about 700 million people) were exposed to severe levels of food insecurity and 17.2 percent (1.3 billion people) experienced food insecurity at moderate levels in 2018 [3]. This means that around 26.4 percent of the world population (about 2 billion people) suffer from food insecurity, which makes it very hard for the UN to maintain the SDG Target 2 to be achieved.

At the same time, agriculture is the second biggest employment sector globally, which corresponds to $28 \%$ of global employment, although there is a significant gap between those employed in the sector in developed and developing countries [6]. According to the World Bank around 1.6 billion people in developing countries will reach working age by 2033 and so it will be a significant challenge to create the supply of jobs while sustaining existing employment, especially in the agrifood sector [7]. Analysis of the situation in rural areas shows that around $78 \%$ of those living on less than USD 2 per day live there, while $63 \%$ of them are employed in agriculture [5].

To meet the demand for food, more investment should be given to promote technical change in agriculture. Digitization and enhancing innovation capacity are essential elements of current policy instruments in order to achieve economic development in the country [8] and global sustainability. Ukraine is chosen as a research base for further analysis.

The economic sectors' share in the structure of gross value added (GVA) and employment level in urban and rural areas in Ukraine are analyzed. Economic sectors' shares in the GVA structure in 2010 and 2017 (the most recent data available as of March 2020) are shown in Table 1.

Table 1

\section{Economic sector shares in the structure of gross value} added in 2010 and 2017, \% [9]

\begin{tabular}{|l|c|c|}
\hline \multicolumn{1}{|c|}{ Economic sector } & $\mathbf{2 0 1 0}$ & $\mathbf{2 0 1 7}^{\mathbf{1}}$ \\
\hline Total & $\mathbf{1 0 0 . 0}$ & $\mathbf{1 0 0 . 0}$ \\
\hline Wholesale and retail trade; repair of motor vehicles and motorcycles & 16.2 & 16.7 \\
\hline Manufacturing industry & 14.9 & 14.7 \\
\hline Agriculture, forestry and fisheries & $\mathbf{8 . 5}$ & $\mathbf{1 2 . 1}$ \\
\hline Transport, warehousing, postal and courier activities & 8.7 & 7.6 \\
\hline Others & 51.7 & 48.9
\end{tabular}

${ }^{1}$ Data is provided without taking into account the temporarily occupied territories of the Autonomous Republic of Crimea and Sevastopol and temporarily occupied territories of Donetsk and Lugansk regions

Data presented in Table 1 point out the importance of agriculture in the country's economy as $12.1 \%$ in GVA in 2017 was contributed by this sector. Moreover, within 7 years agriculture input into GVA has increased at almost $50 \%$. At the same time, according to [9], the increase of gross domestic product (GDP) in 2018 in agriculture was the second biggest and equal to $7.8 \%$. At the same time, according to [10], export of Ukrainian agricultural products in 2017 increased by $16.2 \%$ compared to 2016 and amounted to more than USD 17.9 billion with a total export of USD 53.3 billion.

To evaluate the agriculture contribution in urban and rural areas employment the following data have been analyzed. Population size by urban and rural areas is shown in Table 2 . 
Population size by urban and rural areas in 2016-2018, mln people [9]

\begin{tabular}{|c|c|c|c|}
\hline \multirow{2}{*}{ Population } & \multicolumn{3}{|c|}{ Year } \\
\cline { 2 - 4 } & $\mathbf{2 0 1 6}$ & $\mathbf{2 0 1 7}$ & $\mathbf{2 0 1 8}$ \\
\hline Total & 42760516 & 42584542 & 42386403 \\
\hline Urban population & 29583275 & 29479604 & 29370995 \\
\hline Rural population & 13177241 & 13104938 & 13015408 \\
\hline
\end{tabular}

Data in Table 2 are provided without taking into account the temporarily occupied territories of the Autonomous Republic of Crimea and Sevastopol and temporarily occupied territories of Donetsk and Lugansk regions. The analysis testifies that $30.7 \%$ of the country's population lived in rural areas within 3 years (2016-2018), which means that government policies should pay huge attention to their development in order to maintain the country's sustainability.

The research results testify that agriculture remains significant for livelihoods and employment in the country - almost $18 \%$ of people are employed in this sector (there were employed $2937.6 \mathrm{mln}$ people in agriculture, forestry and fisheries in 2018 out of $16360.9 \mathrm{mln}$ people employed in total). Taking into account that significant migration of people from rural to urban areas in Ukraine takes place because of the lack of jobs in rural areas where agriculture is facing serious problems, it is considered that technologies may be part of this problem solution. Innovative development is also needed in order to increase the share of the agro-industrial complex in the structure of Ukrainian economy, which is appropriate to be developed in the country due to the availability of land resources and comfortable climate conditions for this sector. While talking about innovations, as mentioned in [11], the country's focus on developing its technological capacity as part of its economic development strategy improved its reputation for innovation, which shows tight relation between innovations, technologies and economic development of the state.

The Fourth Industrial Revolution will make the achievement of the "world with zero hunger" by 2030 possible, only if current food systems become more productive, efficient, sustainable, inclusive, transparent, resilient and transformed [2]. The research results testify that, globally, digitization might lead to higher productivity and wealth. Digitization and smart automation are expected to contribute around $14 \%$ to global GDP by 2030, amounted to USD 15 trillion in today's value [6].

To analyze each country's input in its technological development the IMD World Digital Competitiveness Ranking (WDC) is used, which presents overall rankings for 63 economies based on 51 ranked criteria: 31 Hard (Statistics from international regional and national sources) and 20 Survey data [10]. The methodology of the WDC defines digital competitiveness as combination of three main factors: Knowledge, Technology and Future readiness. In turn, each of these factors is divided into 3 sub-factors, which highlight every aspect of the areas analyzed. These 9 sub-factors comprise 51 criteria, although each sub-factor does not necessarily have the same number of criteria (for example, it takes more criteria to assess Training and Education than to evaluate IT integration).

Ukraine's overall performance with detailed description of each factor and its sub-factors rankings in WDC in 2015-2019 is shown in Table 3. Data about the country's performance in the World Competitiveness Ranking, which is another ranking used for analysis of the situation in the researched field, is presented in brackets.

As it can be seen from Table 3, Ukraine's overall performance within 5 years was quite the same with taking its best position in 2018 and worst in 2017 and 2019. Although, the best and worst positions do not vary greatly, which shows serious difficulties in the development of digital technologies in the country in different areas of people lives, as well as in the country in whole. Also, the research results testify that the Knowledge factor, more specifically its sub-factors "Training \& education" and "Scientific concentration" are Ukraine's biggest strengths in the field of digital competitiveness throughout the research period, while Technology (sub-factors "Regulatory framework" and "Capital") and Future readiness (sub-factor "IT integration) are its biggest weaknesses. The analysis of these data points out the areas where additional investment and government policies are essential to be introduced. 
Table 3

Ukraine's overall perfomance in World Digital Competitiveness Ranking in 2015-2019 [12]

\begin{tabular}{|c|c|c|c|c|c|c|}
\hline \multirow[t]{2}{*}{ No } & \multirow[t]{2}{*}{ WDC Ranking sub-factor } & \multicolumn{5}{|c|}{ Year } \\
\hline & & 2015 & 2016 & 2017 & 2018 & 2019 \\
\hline 1 & 2 & 3 & 4 & 5 & 6 & 7 \\
\hline \multicolumn{2}{|c|}{ OVERALL } & $59(60)$ & $59(59)$ & $60(60)$ & $58(59)$ & $60(54)$ \\
\hline \multirow[t]{9}{*}{1} & KNOWLEDGE & 40 & 44 & 45 & 39 & 40 \\
\hline & Talent & 55 & 58 & 57 & 55 & 57 \\
\hline & Training \& education & 15 & 20 & 26 & 22 & 21 \\
\hline & Total public expenditure on education* & 39 & 45 & 45 & 40 & 10 \\
\hline & Pupil-teacher ratio (tertiary education)* & & & & & 11 \\
\hline & Graduates in Sciences* (ICT, Engineering etc.) & & & & & 27 \\
\hline & Scientific concentration & & & & & 49 \\
\hline & Female researchers $*$ & & & & & 16 \\
\hline & $R \& D$ productivity by publication $*$ & & & & & 23 \\
\hline \multirow[t]{9}{*}{2} & TECHNOLOGY & 60 & 60 & 62 & 61 & 61 \\
\hline & Regulatory framework & 55 & 55 & 56 & 54 & 54 \\
\hline & Scientific research legislation $* *$ & & & & & 61 \\
\hline & Intellectual property rights $* *$ & & & & & 61 \\
\hline & Capital & 60 & 60 & 62 & 61 & 62 \\
\hline & Country credit rating $* *$ & & & & & 62 \\
\hline & Venture capital $* *$ & & & & & 61 \\
\hline & Investment in Telecommunications* & & & & & 11 \\
\hline & Technological framework & 60 & 58 & 60 & 57 & 60 \\
\hline \multirow[t]{4}{*}{3} & FUTURE READINESS & 61 & 61 & 61 & 61 & 62 \\
\hline & Adaptive attitudes & 60 & 60 & 58 & 53 & 59 \\
\hline & Business agility & 58 & 59 & 56 & 53 & 45 \\
\hline & $\begin{array}{l}\text { IT integration } \\
\text { Sofware piracy** }\end{array}$ & 61 & 60 & 60 & 61 & $\begin{array}{l}61 \\
60\end{array}$ \\
\hline
\end{tabular}

*Overall top strengths in 2019

**Overall weaknesses in 2019

Doing so is important because of the fact that application of digital technologies, more specifically within the agrifood sector, might improve economic, social, cultural and environmental aspects of the country's life through the use of different types of resources. In this context, three basic spheres to identify the state of digital technologies in agriculture and rural areas are determined, identifying possible areas for improvement:

1. economic (agricultural technologies could increase productivity, market opportunities, sector and national GDP; reduce production and logistic costs, food loss and waste; bring sustainability);

2. social and cultural (technologies could create an integrating effect at a social and cultural level through the communication mechanisms they provide. However, at the same time, those who do not have the possibility of accessing them (digital divide) are excluded from their benefits);

3. environmental (smart agriculture allows to optimize agricultural production processes, prevent and adapt to climate change, promote best use of natural resources).

To analyze the benefits and challenges of digital technologies use in the agrofood sector in rural areas of Ukraine the attention is paid to the specifics of Digital Agriculture and key factors of transition to digital farming accordingly. The main document for Ukraine in this context is the "Digital Agenda 2020", which outlines the main principles on how the country should develop state policy in the field of IT, e-governance and use of national e-information resources.

It is expected that development of digital economy in Ukraine will enable to:

- create the conditions for 8-10 times economy growth over the next 10 years;

- increase productivity growth significantly;

- make a technological leap for the Ukrainian economy; 
- significantly increase the Ukrainian economy competitiveness at global markets;

- create new business models, segments and sectors, opportunities to quickly, conveniently and cheaply develop, scale and capitalize on any business;

- create new jobs and demand for new professions [13].

Agro-processing industry is one of the target industries in Ukraine to implement relevant Industry 4.0 initiatives and projects [14]. Digital Agriculture is a fundamentally new management strategy in agronomy, based on the application of digital Technologies, which can be classified as follows [6]:

1. mobile devices and social media;

2. precision agriculture and remote sensing technologies (IoT, GNSS, RTK, VRT, PLF, UAV and satellite imagery);

3. Big Data, cloud, analytics and Cybersecurity;

4. integration and coordination (blockchain, ERP, financing and insurance systems);

5. intelligent systems (Deep Learning, Machine Learning and Artificial Intelligence , and robotics and autonomous systems).

This is a new stage in the development of the agrifood sector associated with the use of geoinformation systems, global positioning, on-board computers, control and enforcement mechanisms that can differentiate treatments, fertilizer rates, chemical ameliorants and plant protection products. Digital technologies in agriculture are aimed primarily at economic efficiency and soil protection, increasing yields per hectare of land, reducing crop losses in the fields and, in general, increasing the utilization rate of the country's land bank and maintain food security. However, first and foremost, the key goal of digital farming is a healthy society that needs to consume healthy, unsaturated agricultural chemicals and fertilizers. Otherwise there might be spread of pathologies among the younger generation, reducing life expectancy, which therefore will affect the demographic situation in the country, economy and the world.

That is why "Digital agricultural revolution" could help to ensure that agriculture meets the needs of global population. Main benefits of it to take place are determined as follows [5].

1. Optimization, individualization, intelligence and anticipation of resources management throughout the system.

2. It functions in real time in a hyper-connected way, driven by data.

3. Value chains become traceable and coordinated at the most detailed level, whilst different fields, crops and animals can be accurately managed to their own optimal prescriptions.

4. It creates systems that are adaptable to changes, such as those caused by climate change.

5. This, in turn, results in greater food security, profitability and sustainability.

6. In the context of the SDG, digital agriculture has the potential to deliver economic benefits through increased agricultural productivity, cost efficiency and market opportunities.

7. It increases communication and inclusivity, optimizes resource use as social and cultural benefits and adapts to climate change as environmental ones.

8. Access to digital technology can offer significant advantages to smallholder farmers and other rural businesses by providing links to suppliers and users to build strategic partnerships, access support services, such as training, finance and legal services, and, critically, reach markets and customers.

However, the introduction of digital technologies in rural areas can be a challenge. One of the challenges is that rural population around the world is declining accompanied by limited education and employment opportunities. There is often a lack of infrastructure, including basic IT infrastructure. Costs associated with IT infrastructure present a major challenge in rural areas, which also face the risk of a "double digital divide" that means that on the supply side, they are still lagging behind in terms of the provision of the Next Generation Access infrastructure and on the demand side, many rural areas lack the basic skills and knowledge of digital technology potential, so that even if the "digital highways" are in place, they may remain under-exploited in terms of service provision, business use, or customer take up [15]. So, another barrier of digital agriculture in rural areas to take place is digital education, which is difficult to be applied there because of the costs of information and communication technology (ICT) courses to be introduced [16]; lack of infrastructure investment; distance to schools; classroom size; budget available for education. 
Significant worldwide experience in promoting digital agriculture is seen through the farmbusiness segment [17]. There is significant potential for the use of modern digital technologies in the activities of enterprises. It is necessary to take into account that digital enterprises have significant potential to accelerate innovation processes [18]. After all, the low level of economic development in rural areas of the country results in permanent migration of youth from rural to urban areas, high unemployment and low incomes in rural areas, destruction of social and engineering infrastructure.

\section{Conclusions}

Therefore, importance of digital agriculture use in rural areas is in the following:

1. The introduction of digital agriculture is an important measure of agricultural intensification without significant additional costs.

2. Digital agriculture is considered to be one of the next stages in the agricultural production development, with the greatest possible savings of resources and effective protection of the environment and health. This means that "digitization" should be used as an effective tool to bridging the "digital" gap and socio-economic revival of rural areas.

3. Digital agriculture is soil-protective, innovative and competitive technology that contributes to the structural and technological restructuring of agrosphere and enhancement of the country's economic potential.

4. The attention of government policies should be paid to the creation of digital infrastructure in rural areas; provision of constant support for production, technical, educational and scientific aspects of digital agriculture; training of skilled professionals etc.

5. Introduction of "digital" technologies will help increase the attractiveness of work in agrosphere and gradually transform the agronomist into a modern manager, increase the level of economic culture and environmental awareness in rural areas.

\section{References}

[1] The United Nations Department of Economic and Social Affairs. World Population Prospects: Highlights. 2019. [online] [01.03.2020]. Available at:

https://www.un.org/development/desa/publications/world-population-prospects-2019-highlights.

[2] The United Nations Department of Economic and Social Affairs. World Population Prospects: The 2017 Revision. [online] [01.03.2020]. Available at:

https://www.un.org/development/desa/publications/world-population-prospects-the-2017revision.l

[3] The State of Food Security and Nutrition in the World. Sefaguarding Against Economic Slowdowns and Downturns (2019). [online] [01.03.2020]. Available at: http://www.fao.org/3/ca5162en/ca5162en.pdf.

[4] The United Nations Department of Economic and Social Affairs. Revision of World Urbanization Prospects. 2018. [online] [10.02.2020]. Available at:

https://www.un.org/development/desa/publications/2018-revision-of-world-urbanizationprospects.html.

[5] The Future of Food and Agriculture - Alternative Pathways to 2050. 2018. [online] [20.02.2020]. Available at: http://www.fao.org/3/I8429EN/i8429en.pdf.

[6] Digital Technologies in Agriculture and Rural Areas Briefing Paper. 2019. [online] [10.02.2020]. Available at: http://www.fao.org/3/ca4887en/ca4887en.pdf.

[7] World Bank Annual Report. 2017. [online] [25.02.2020]. Available at: http://documents.worldbank.org/curated/en/143021506909711004/World-Bank-Annual-Report2017.

[8] Aditi K. The Promise and Reality of Digital Technologies in Bridging the Rural-Urban Divide. 2019. [online] [01.03.2020] Available at: https://www.orfonline.org/expert-speak/promise-realitydigital-technologies-bridging-rural-urban-divide-56959.

[9] State Statistics Service of Ukraine. [online] [03.03.2020]. Available at: http://www.ukrstat.gov.ua/.

[10] Ministry of Agrarian Policy and Food of Ukraine. 2018. [online] [02.02.2020]. Available at: https://agro.me.gov.ua/ua. 
[11] Kramar I., Tsikh H., Halushchak I. Ukraine's perspectives in industry 4.0. Business Risk in Changing Dynamics of Global Village 2: Monograph / Edited by Nataliia Marynenko, Pradeep Kumar, Iryna Kramar. Nysa: Publishing House of the University of Applied Sciences in Nysa. 514 p., pp. 505-513.

[12] The IMD World Digital Competitiveness Ranking. 2019. [online] [15.02.2020]. Available at: https://www.imd.org/wcc/world-competitiveness-center-rankings/world-digital-competitivenessrankings-2019/.

[13] Ukraine 2030E - country with developed digital economy. 2018. [online] [01.03.2020]. Available at: https://strategy.uifuture.org/kraina-z-rozvinutoyu-cifrovoyu-ekonomikoyu.html.

[14] Ukrainian Chamber of Commerce and Industry. 2017. [online] [10.02.2020]. Available at: https://ucci.org.ua/uploads/files/58e78ee3c3922.pdf.

[15]Digital Divide Between Rural and Urban Areas. Workshop 1 - Rural Digital Hubs \ ENRD Seminar on "Revitalising Rural Areas through Business Innovation". 2017. [online] [11.02.2020]. Available at: https://enrd.ec.europa.eu/sites/enrd/files/s4_rural-businesses-factsheet_digitalhubs.pdf.

[16] Grimes S. The digital economy challenge facing peripheral rural areas. 2003. [online] [26.04.2020]. Available at: http://doi.org/10.1191/0309132503ph421oa.

[17] Philip L. J., Townsend L., Roberts E., Beel D. The rural digital economy. 2015. [online] [27.04.2020]. Available at: https://doi.org/10.1080/14702541.2015.1083732

[18] Andriushchenko K., Rudyk V., Riabchenko O. and others. Processes of managing information infrastructure of a digital enterprise in the framework of the "Industry 4.0" concept. EasternEuropean Journal of Enterprise Technologies, 1/3(97), 2019, pp. 60-72. DOI: $10.15587 / 1729-4061.2019 .157765$ 